\title{
DETECTION OF HEPATITIS A ANTIBODIES BY ELISA USING SALIVA AS CLINICAL SAMPLES
}

\author{
Isabel Takano OBA(1), Angela Maria Miranda SPINA(1), Cláudia Patara SARACENI(1), Marcílio Figueiredo LEMOS(1), Rita de Cássia Ferreira Andrade SENHORAS(2), \\ Regina Célia MOREIRA(1) \& Celso Francisco Hernandes GRANATO(3)
}

\begin{abstract}
SUMMARY
The possibility of detecting acute infection and immunity using body fluids that are easier to collect than blood, mainly in children, would facilitate the investigation and follow-up of outbreaks of hepatitis A (HAV). Our study was carried out to evaluate the detection of anti-HAV IgM, IgA and total antibodies in saliva using serum samples as reference. Forty three paired serum and saliva samples were analyzed. From this total, 24 samples were obtained from children and 1 from one adult during the course of acute hepatitis A; an additional 18 samples were obtained from health professionals from Adolfo Lutz Institute. The sensitivity to detect anti-HAV IgM was $100 \%$ (95\%CI: 79.1 to $100.0 \%$ ), employing saliva as clinical samples. In detecting anti-HAV IgA, the sensitivity was $80.8 \%$ (95\%CI: 60.0 to $92.7 \%$ ) and for the total antibodies was $82.1 \%$ (95\%CI: 62.4 to $93.2 \%$ ). The specificity was $100 \%$ for each. The rate of agreement was high comparing the results of serum and saliva samples for detecting HAV antibodies. We conclude that saliva is an acceptable alternative specimen for diagnosing acute hepatitis A infection, and for screening individuals to receive hepatitis A vaccine or immunoglobulin.
\end{abstract}

KEYWORDS: Hepatitis A; Saliva; Antibodies; Vaccine

\section{INTRODUCTION}

Hepatitis A is one of the most common causes of infectious hepatitis in the World and the major means of transmission include contamination of water supply and food. It is caused by a virus that belongs to the Picornaviridae family, genus Hepatovirus, HAV (HOLLINGER \& TICEHURST, 1996; KOFF, 1998).

Brazil is a country with a suboptimal network of public sanitation. The prevalence of anti-HAV IgG antibody is high, reaching about $90 \%$ of children by ten years of age (CARRILHO \& SILVA, 1995). This epidemiological profile could be changing, at least in certain social groups, according to PINHO et al. (1998), who carried out a seroepidemiological study on universitary students from a high socialeconomic level, and found within that population only $19.6 \%$ were antiHAV positive. Clinically, hepatitis A follows an anicteric or completely asymptomatic course in $95 \%$ of children, up to five years of age (ROSS et al., 1991). In adults the disease is more severe and prolonged (LEDNAR et al., 1985; ZACHOVAL \& DEINHARDT, 1998), but does not lead to a chronic carrier state (BATTEGAY et al., 1995).

An initial serological response against $\mathrm{HAV}$ is directly related to the humoral immunity, given the formation of IgM, IgG and IgA antibodies, which are detectable at the onset of symptoms (ROSS et al., 1991; LEMON, 1985).

The anti-HAV IgM antibody is transient, generally persisting for six to eight months after the acute infection. Its detection is therefore indicative of recent infection by HAV (KOFF, 1992; LEMON \& STAPLETON, 1998; LOCARNINI et al., 1979).

The anti-HAV IgG antibody increases gradually, reaching high levels during the convalescent phase (STAPLETON et al., 1991) and remains for life, conferring immunity against reinfection.

Secretory $\operatorname{IgA}$ is associated with intestinal resistance to many viral infections, as is the case of the Polioviruses. The oral vaccine, obtained from attenuated viral strains, induces the production of this antibody and protects against enteric reinfection. In spite of this, some authors have shown that in case of infection by HAV, intestinal immunity does not represent protection against this virus (STAPLETON, 1995).

Laboratory diagnosis in cases of Hepatitis A is established by measuring in the serum the levels of intracellular hepatic enzymes (ALT and AST) as well as by the detection of anti-HAV IgM antibodies in blood samples (HESS et al., 1995).

\footnotetext{
(1) Department of Virology, Instituto Adolfo Lutz, SP, Brazil.

(2) Health Center, São Sebastião da Grama, SP, Brazil.

(3) Department of Virology, School of Medicine, Federal University of São Paulo, SP, Brazil.

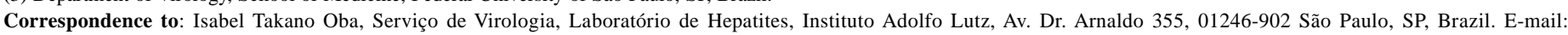
isabeltoba@hotmail.com
} 


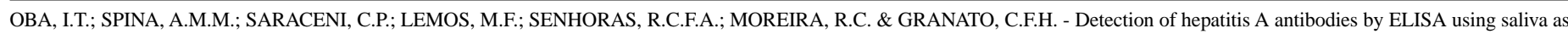
clinical samples. Rev. Inst. Med. trop. S. Paulo, 42(4): 197-200, 2000.

The difficulty in collecting blood samples, mainly in children, and the ease and reliability of the collection of saliva samples have led various authors to develop methods, or adapt already existing techniques, for the detection of specific antibodies found in saliva (PARRY et al., 1987) and in urine (PARRY, 1993).

During outbreaks of Hepatitis A, collection of blood samples is usually necessary for serological testing and establishment of etiological diagnosis. This diagnosis allows the determination of measures for prevention and control of the disease. The general acceptance of collecting saliva samples is far greater in the entire community and this would greatly facilitate investigations and follow-up of outbreaks (PARRY, 1993). Saliva samples are less expensive to collect when compared to blood samples.

The detection of antibodies in saliva was initially demonstrated by ARCHIBALD et al. (1986). Since then, various studies were undertaken, utilizing saliva samples not only for the diagnosis of recent and past infection, but for evaluation of the response of the Hepatitis A vaccine (LAUFER et al., 1995; OCHNUI et al., 1997; PARRY et al., 1987; PARRY et al., 1989; PARRY, 1993; PIACENTINI et al., 1993; THIEME et al., 1992).

The advantage of utilizing saliva in tests for the diagnosis of Hepatitis $\mathrm{A}$ is the ease of collection, making this a satisfactory and convenient alternative (PARRY et al., 1989), especially if we consider that in this epidemiological setting the majority of the patients are children.

In the present study, we compared results obtained by the detection of antibodies of the IgM, IgA and IgG class against HAV, in both saliva and serum samples. We evaluated the possibility of replacing serum by saliva samples for diagnosis and for selection of candidates for vaccination against Hepatitis $\mathrm{A}$.

\section{MATERIAL AND METHODS}

Fourty-three paired serum and saliva samples were analyzed. Twentyfour of them were obtained from children involved in an outbreak of hepatitis A which occurred in the country of São Sebastião da Grama, São Paulo State, Brazil. One set of samples came from an adult with acute hepatitis A and 18 other set of samples were provided by employees from the Instituto Adolfo Lutz, apparently healthy and without clinical or epidemiological risks of hepatitis.

Blood samples were subjected to centrifugation and serum was separated and transferred to previously labelled $5 \mathrm{~mL}$ test tubes. Saliva samples were obtained by utilizing Omni-SAL saliva collectors (Saliva Diagnostic Systems, Singapore) and refrigerated at $-20{ }^{\circ} \mathrm{C}$ until the moment of testing. They were tested diluted 1:5, in phosphate buffered saline ( $\mathrm{pH} 7.4$ ) with $1 \%$ bovine serum albumine (PBS-A). Serum samples and the results obtained with them were used as reference samples, while the saliva samples were utilized as alternatives.

The presence of anti-HAV antibodies of $\operatorname{IgG}, \operatorname{IgM}$ and $\operatorname{IgA}$ classes were assayed in both serum and saliva samples. In saliva samples, IgG as well as IgM antibodies were detected by adaptations of commercial enzyme immunoassays (SORIN ${ }^{\circledR}$ ETI-AB-HAVK-2, ETI-AB-HAVK-3 and ETI-HA-IgMK-2). Serum samples were substituted by saliva in the first incubation period. The tests on serum were performed according to the instructions of the producer.

For the experiments to detect $\operatorname{IgA}$ class antibody, the samples were analyzed using SORIN ${ }^{\circledR}$ ETI-AB-HAVK-3 kits, with some modifications.

According to the procedures described by CROWTHER (1995), polystyrene microplates were coated with $100 \mu \mathrm{L}$ of the goat anti-human IgA antibody (SIGMA), diluted at 1:800 in $50 \mathrm{mM}$ carbonate-bicarbonate buffer ( $\mathrm{pH}$ 9.6). After a 16 hours incubation, blocking was achieved with $100 \mu \mathrm{L}$ of PBS-A. One hundred microliters of dilution of saliva samples in PBS-A 1:5 was added and incubated at $4{ }^{\circ} \mathrm{C}$ for 18 to 20 hours. After this period, the microplate was washed four times with a PBS/Tween $(0.5 \%)$ solution and $100 \mu \mathrm{L}$ of HAV antigen provided by the commercial kit were added, and incubated at $37{ }^{\circ} \mathrm{C}$ for 2 hours. Following this incubation and after washing the microplate wells, $100 \mu \mathrm{L}$ conjugate were added (human antibody anti-HAV conjugated with peroxidase, a reagent included in the SORIN ${ }^{\circledR}$-ETI-AB-HAVK-3 kit). The final step of the reaction was the addition to each well of $100 \mu \mathrm{L}$ of a substrate solution containing tetrametilbenzidine and hydrogen peroxide buffered citrate. The microplate was incubated at room temperature for 30 minutes, protected from light, and the reaction was later interrupted by the addition of $100 \mu \mathrm{L}$ of sulfuric acid $(1 \mathrm{~N})$ to each well. The reading of the reaction was done using a microplate spectrophotometer (Microwell System Reader 510 - Organon Teknika ${ }^{\circledR}$, filter $492 \mathrm{~nm}$ and $600 \mathrm{~nm}$ ) and the cut-off of the reaction was determined by calculating the mean optical density (OD) of four known negative samples and adding three standard deviations. Samples which showed an OD above the cut-off value were considered positive.

Positive and negative controls were included in all experiments.

In order to assess the statistical significance of the association, $95 \%$ confidence intervals (CI) were used.

\section{RESULTS}

Detection of total anti-HAV in saliva samples. Of the 43 paired serum and saliva samples 28 were collected from serologically positive subjects. A positive result was observed in $23 / 28$, oral fluid specimens, showing a sensitivity of $82.1 \%$ (95\%CI: 62.4 to $93.2 \%$ ); 15 subjects were negative for serum as well as saliva, resulting in a specificity of $100 \%$ (95\%CI: 74.7 to $100.0 \%$ ). The agreement between the results of the two clinical samples was $88.4 \%$.

Detection of anti-HAV antibodies of the IgA class in saliva samples. Of the 43 subjects 26 had detectable IgA anti-HAV in their serum, of which 21 were also positive for this marker in saliva, representing a sensitivity of $80.8 \%$ (95\%CI: 60.0 to $92.7 \%$ ) in both clinical samples. Seventeen matched serum and saliva samples were negative for this marker, resulting in a specificity of $100 \%$ (95\% CI: 77.1 to $100.0 \%$ ). The agreement between the results was $88.4 \%$.

Detection of anti-HAV antibodies of the IgM class in saliva samples. Of the 43 matched sample sets analyzed, 19 were positive for IgM antibodies while 24 were negative for this marker. We observed complete agreement for the detection of the anti-HAV of the IgM class, utilizing the same methodology but different clinical samples (serum 


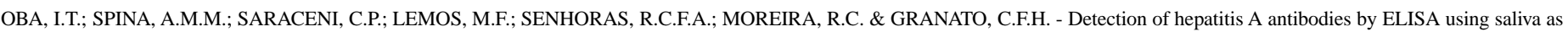
clinical samples. Rev. Inst. Med. trop. S. Paulo, 42(4): 197-200, 2000.

and saliva), representing a sensitivitiy of $100.0 \%$ (95\%CI: 79.1 to $100.0 \%$ ) and specificity of $100.0 \%$ (95\%CI: 82.8 to $100.0 \%$ ).

\section{DISCUSSION}

Hepatitis caused by HAV can not be differentiated from other etiologies, based only upon the clinical and epidemiologic characteristics. The serum test for the detection of anti-HAV IgM is necessary to confirm the etiologic diagnosis of the acute infection, while the detection of $\operatorname{IgG}$ antibodies indicates immunity and long-lasting protection against the virus. In the epidemiological setting found in Brazil, the finding of $\operatorname{IgG}$ anti-HAV rarely can be used to clarify the diagnosis. For routine laboratory diagnosis of acute Hepatitis A, commercially available immunoenzymatic tests were used, employing sera as clinical samples.

Similarly our results demonstrate that saliva can be utilized in tests for the detection of total antibodies against HAV, and that this strategy could be applicable to screening vaccine candidates or candidates for gammaglobulin injections, with a reasonable degree of confidence, as we obtained a sensitivity of $82.1 \%$ and a specificity of $100 \%$ for this marker.

STAPLETON (1995) and STAPLETON et al. (1991) have demonstrated, by means of radioimmunoassay, the presence of anti-HAV IgA, in 9 out of 14 saliva samples obtained from individuals during an outbreak of Hepatitis A, 56 days after the onset of jaundice.

The detection of anti-HAV $\operatorname{IgA}$ in saliva and serum samples in our study presented a sensitivity of $80.8 \%$ and a specificity of $100 \%$. Furthermore, an agreement of $88.4 \%$ between both types of samples, serum and saliva, was obtained. We observed that anti-HAV IgA antibodies in saliva and serum are slightly less detectable than the antiHAV IgG (21 and 23 out of 43 versus 23 and 26 out of 43).

LAUFER et al. (1995) analyzed the presence of IgG in saliva in vaccinated individuals as well as in non-vaccinated people. They observed $100 \%$ of agreement in the detection of IgG acquired after natural infection, while concordance among the vaccinated individuals was only $28 \%$. This fact can be explained by the difference in the levels of antibodies which were naturally produced as opposed to the ones acquired by active immunization. In our study, we do not evaluate the response to vaccination against Hepatitis A.

In relation to the detection of IgM, PARRY (1993) and PARRY et al. $(1987,1989)$ using the competition radioimmunoassay, demonstrated that anti-HAV IgM can be reliably detected in the saliva of patients with acute or recently acquired Hepatitis A. Fourteen serum and saliva samples with recent hepatitis, collected simultaneously, were tested for anti-HAV IgM. Eight cases were confirmed as acute Hepatitis A by serum examination. The reactivity in serum was very similar to the one found in saliva. These authors observed that anti-HAV IgM in saliva samples can be detected, in moderate levels, from two to four months after the onset of symptoms. After this period, detection became practically impossible.

Similarly, PIACENTINI et al. (1993), obtained a sensitivity of $100 \%$ and a specificity of $98 \%$ in anti-HAV IgM detection tests in paired serum and saliva samples.
In our study, anti-HAV IgM was detected in 19 simultaneously collected serum and saliva samples, showing a concordance of $100 \%$.

Altogether these data suggest the possibility of substitution of serum by saliva as clinical samples for the diagnosis of acute Hepatitis A.

BULL et al.(1989), studying an outbreak of Hepatitis A in a school, utilized saliva samples to carry out an epidemiologic investigation. Two samples were collected from the entire school community at an interval of ten weeks. In four individuals with acute Hepatitis A anti-HAV IgM was detected. It persisted in the saliva for two to three months after initiation of the clinical signs (jaundice), confirming the results that PARRY et al. (1989) carried out at the same time.

THIEME et al. (1992) addressed the issue of the longevity of antibody detection. The detection of anti-HAV IgM in saliva and serum samples showed $100 \%$ sensitivity and $98 \%$ specificity. In the longitudinal study of HAV in 5 patients, the IgM antibody decline in saliva and serum samples was similar for both, though two patients showed a decline in saliva samples before they did in serum samples. This decline could have occurred due to the low sensitivity of the saliva test in relation to the serum test or to the degradation of the antibodies by the salivary enzymes. Anti-HAV IgM was detected in the saliva for 60 days and the total anti-HAV (IgM and IgG) was detected for more than 320 days after the onset of symptoms. The authors demonstrated that saliva can be utilized as clinical samples for the diagnosis of acute infection and monitoring of immunization against HAV.

Our study demonstrates and confirms the possibility of substitution of serum by saliva in laboratory diagnosis of hepatitis A and in the selection of individual candidates for active or passive immunization.

\section{RESUMO}

\section{Detecção de anticorpos anti-VHA em amostras de saliva utilizando teste imuno-enzimático}

A possibilidade de identificar infecções presentes ou passadas utilizando fluidos corpóreos que seriam mais facilmente coletados do que o sangue, principalmente em crianças, facilitaria grandemente a investigação e o acompanhamento de surtos de hepatite A, que ocorrem com muita freqüência em nosso meio.

Nosso estudo foi desenvolvido com a finalidade de avaliar a detecção dos anticorpos anti-VHA, da classe $\operatorname{Ig} \mathrm{A}$, IgM, e anticorpos totais em amostras de saliva, usando amostras de soro como padrão.

Foram estudadas 43 amostras pareadas de saliva e de soro, colhidas de 24 crianças e de um adulto durante um surto de hepatite A, e de 18 funcionários do Instituto Adolfo Lutz.

Empregando saliva como amostra clínica, a sensibilidade para a detecção de anti-VHA IgM foi de $100,0 \%$, de anti-VHA $\operatorname{IgA}$ foi de $80,8 \%$ e de anti-VHA total foi de $82,1 \%$. Não houve nenhum resultado falso-positivo, sendo a especificidade de $100 \%$.

A concordância foi alta entre os resultados das amostras de saliva e soro na detecção dos anticorpos, indicando que amostras de saliva podem 
OBA, I.T.; SPINA, A.M.M.; SARACENI, C.P.; LEMOS, M.F.; SENHORAS, R.C.F.A.; MOREIRA, R.C. \& GRANATO, C.F.H. - Detection of hepatitis A antibodies by ELISA using saliva as clinical samples. Rev. Inst. Med. trop. S. Paulo, 42(4): 197-200, 2000.

ser utilizadas no diagnóstico de infecção aguda pelo VHA e na seleção de indivíduos para vacinação contra o VHA, para conter surtos.

\section{REFERENCES}

1. ARCHIBALD, D.W.; ZON, L.I.; GROOPMAN, J.E. et al. - Salivary antibodies as a means of detecting human $\mathrm{T}$ cell lymphotropic virus type III/ lymphadenopathyassociated virus infection. J. clin. Microbiol., 24: 873-875, 1986.

2. BATTEGAY, M.; GUST, I.D. \& FEINSTONE, S.M. - Hepatitis A virus. In: MANDELL, G.L.; BENNETT, J. \& DOLIN, R., ed. Principles and practice of infectious diseases. 4. ed. Edinburgh, Churchill Livingstone, 1995. p. 1636-1656.

3. BULL, A.R.; KIMMANCE, K.J.; PARRY, J.V. \& PERRY, K.R. - Investigation of an outbreak of hepatitis A simplified by salivary antibody testing. Epidem. Infect., 103: $371-376,1989$.

4. CARRILHO, F.J. \& SILVA, L.C. - Epidemiologia. In: SILVA, L.C. da, ed. Hepatites agudas e crônicas. 2. ed. São Paulo, Sarvier, 1995. p. 73-87.

5. CROWTHER, J.R. - Stages in ELISA. In: CROWTER, J.R. ELISA: theory and practice. New Jersey, Humana Press, 1995. p. 63-97.

6. HESS, G.; FAATZ, E.; MELCHIOR, W. \& BAYER, H. - Analysis of immunoassays to detect antibodies to hepatitis A virus (anti-HAV) and anti-HAV immunoglobulin M. J. virol. Meth., 51: 221-228, 1995.

7. HOLLINGER, F.B. \& TICEHURST, J.R. - Hepatitis A. In: FIELDS, B.N.; KNIPE, D.M. \& HOWLEY, P.M., ed. Virology. Philadelphia, Raven Press, 1996. p. 735-781.

8. KOFF, R.S. - Clinical manifestation and diagnosis of hepatitis A virus infection. Vaccine, 10: S15-S17, 1992.

9. KOFF, R.S. - Hepatitis A. Lancet, 351: 1643-1649, 1998.

10. LAUFER, D.S.; HURNI, W.; WATSON, B. et al.- Saliva and serum as diagnostic media for antibody to hepatitis A virus in adults and in individuals who have received an inactivated hepatitis A vaccine. Clin. infect. Dis., 20: 868-871, 1995.

11. LEDNAR, M.W.; LEMON, M.S. \& KIRKPATRICK, W.J. - Frequency of illness associated with epidemic hepatitis A virus infections in adults. Amer. J. Epidem., 122: 226-233, 1985.

12. LEMON, M.S. - Type A viral hepatitis: new developments in an old disease medical progress. New Engl. J. Med., 313: 1059-1066, 1985.
13. LEMON, S.M. \& STAPLETON, J.T. - Prevention. In: ZUCKERMAN, A.J. \& THOMAS, H.C., ed. Viral hepatitis: scientific basis and clinical management. Edinburgh, Churchill Livingstone, 1998. p. 63-76.

14. LOCARNINI, A.S.; COULEPIS, G.A.; STRATTON, M.A.; KALDOR, J. \& GUST, D.I. - Solid-phase enzyme-linked immunosorbent assay for detection of hepatitis A-specific immunoglobulin M. J. clin. Microbiol., 9: 459-465, 1979.

15. OCHNUI, J.J.; SCHEIFELE, D.W.; HO, M. \& MITCHELL, L.E.A. - New, ultrasensitive enzyme immunoassay for detecting vaccine and-disease-induced hepatitis A virusspecific immunoglobulin G in saliva. J. clin. Microbiol., 35: 98-101, 1997.

16. PARRY, J.V. - Simple and reliable salivary test for HIV and hepatitis A and B virus diagnosis and surveillance. Ann. N. Y. Acad. Sci., 694: 216-233, 1993.

17. PARRY, J.V.; PERRY, K.R. \& MORTIMER, P.P. - Sensitive assays for viral antibodies in saliva: an alternative to tests on serum. Lancet, 2: 72-75, 1987.

18. PARRY, J.V.; PERRY, K.R.; PANDAY, S. \& MORTIMER, P.P. - Diagnosis of hepatitis A and B by testing saliva. J. med. Virol., 28: 255-260, 1989.

19. PIACENTINI, S.C.; THIEME, T.R.; BELLER, M. \& DAVIDSON, S.L. - Diagnosis of hepatitis A, B, and C using oral samples. Ann. N. Y. Acad. Sci., 694: 334-336, 1993.

20. PINHO, J.R.R.; SUMITA, L.M.; MOREIRA, R.C. et al. - Duality of patterns in hepatitis A epidemiology: a study involving two socioeconomically distinct populations in Campinas, São Paulo State, Brazil. Rev. Inst. Med. trop. S. Paulo, 40: 105-106, 1998.

21. ROSS, B.C.; ANDERSON, D.A. \& GUST, I.D. - Hepatitis A virus and hepatitis A infection. Advanc. Virus Res., 39: 209-253, 1991.

22. STAPLETON, J.T. - Host immune response to hepatitis A virus. J. infect. Dis., 171(suppl.1): S9-S14, 1995.

23. STAPLETON, J.T.; LANGE, D.K.; LeDUC, J.W. et al. - The role of secretory immunity in hepatitis A virus infection. J. infect. Dis., 163: 7-11, 1991.

24. THIEME, T.; YOSHIHARA, P.; PIACENTINI, S. \& BELLER, M. - Clinical evaluation of oral fluid samples for diagnosis of viral hepatitis. J. clin. Microbiol., 30: 10761079, 1992

25. ZACHOVAL, R. \& DEINHARDT, F. - Hepatitis A virus: natural history and experimental models. In: ZUCKERMAN, A.J. \& THOMAS, H., ed. Viral hepatitis: scientific basis and clinical management. 2. ed. London, Churchill Livingstone, 1998. p. 4358 .

Received: 03 February 2000

Accepted: 29 March 2000 